\title{
Methods for assessing the vulnerability of African fisheries resources to climate change
}

\author{
Ihor Hlohowskyj ${ }^{1}$, Michael S. Brody ${ }^{2}$, Robert T. Lackey ${ }^{3}$ \\ ${ }^{1}$ Environmental Assessment Division, Argonne National Laboratory, 9700 S. Cass Ave, Argonne, Illinois 6043, USA \\ ${ }^{2}$ Office of Policy, Planning, and Evaluation, U.S. Environmental Protection Agency, 401 M Street, SW (2137), \\ Washington, DC 20460, USA \\ ${ }^{3}$ Environmental Research Laboratory, U.S. Environmental Protection Agency, 200 SW 35th Street, Corvallis, \\ Oregon 97333. USA
}

\begin{abstract}
Because of the dietary and financial importance of fisheries resources in many African countries, concerns have been expressed regarding the potential for adverse impacts to fisheries resources from climate change, and a need has been identified for assessment tools that can evaluate the potential for impacts in a timely and cost-effective manner. This paper presents a framework and set of methods for assessing the potential effects of climate change on fisheries resources in Africa. The framework identifies the need to first link predicted climate changes to changes in the aquatic environment, and only then can potential impacts to aquatic resources be evaluated. The approach developed for Africa was constrained by several factors, including availability of existing data and assessment technologies, and the need for a rapid evaluation of potential climate impacts. The assessment approach employs a variety of methods including empirical models which predict changes in mortality, maximum sustainable yield, and yearly catch, a bioenergetics model, and a habitat suitability model. Previously developed or newly derived site-specific empirical models can be used to compare mortality, yield, and annual catch estimates among historic, current, and predicted climate conditions. Similarly, bioenergetics modeling can be used to compare growth rates and biomass production among different climate conditions. Habitat suitability models can be developed for current climate conditions, and the effects of changes in climate-driven habitat variables such as water depth, temperature, and current velocity on habitat suitability can be evaluated for different climate conditions. Use of these approaches is recommended because they can utilize existing ecological data and do not require extensive new data collection activities, they are not technologically complex, and they can provide evaluations of potential climate change impacts in a timely and cost-effective manner.
\end{abstract}

KEY WORDS: Bioenergetics model · Climate change - Empirical models · Fish yield · Habitat suitability index Tropical freshwater fisheries

\section{INTRODUCTION}

A variety of changes in climatic conditions following atmospheric $\mathrm{CO}_{2}$ enrichment have been predicted (Smith \& Tirpak 1989, Mearns et al. 1990, Meisner \& Shuter 1992). These predictions include increased air temperatures, regional shifts in precipitation, and seasonal changes in the timing and duration of precipitation events and sea level rise. These climatic changes can, in turn, affect water temperatures, alter the timing and duration of extreme temperature conditions, change the magnitude and pattern of annual stream flow, and alter surface water elevations and shorelines of lakes and reservoirs (Carpenter et al. 1992).

Climate change country studies provide technical support to help developing countries and countries with economies in transition prepare studies that address climate change (Dixon et al. 1996). The country studies include 3 principle elements: inventories of greenhouse gas emissions; assessments of vulnerability of selected resources to climate change and adaptive responses for limiting potential adverse impacts; and assessments of mitigation options to reduce greenhouse gas emissions or enhance carbon sinks (Ramos- 
Mane \& Benioff 1995). Natural resource sectors initially addressed by the U.S. Country Studies Program include energy, forestry, agriculture, and water. Several African countries identified the need for the development of vulnerability assessment guidance for fisheries resources in Africa, particularly when the fisheries represent a major food or economic resource. In addition, some countries are concerned with maintaining the diversity of their fish species.

In this paper we present an approach and identify a set of methodologies for evaluating the potential effects of climate change on fisheries resources in Africa. To identify assessment approaches suitable for Africa, we reviewed existing methods used in other parts of the world for evaluating climate change impacts to fisheries resources, identified the climate factors that may affect fisheries resources in Africa, and evaluated the applicability of those approaches to Africa.

\section{CURRENT APPROACHES FOR ASSESSING THE EFFECTS OF CLIMATE CHANGE ON FISHES}

The vulnerability of fishes to climate change is dependent on the nature of the predicted change as well as the nature of the fishery and its species and habitats (Regier \& Meisner 1990). Although climatic changes will affect most species to some degree, some species may be particularly vulnerable. For example, the isolating factors which led to the evolution of the unique fish assemblages present in African rift valley lakes such as Lake Malawi also limit or prevent the migration of fishes to aquatic habitats in other drainage basins. In the event of climate related reduc- tions in habitat quality or quantity, fishes in these habitats would be unable to migrate to potentially more suitable habitats in other drainage basins. In riverine systems, many species rely on inundated floodplains for reproduction, nursery habitats, and successful recruitment, and the life cycles of these species are strongly dependent on the temporal cycle of the rainy and dry seasons (Welcomme 1985, Lowe-McConnell 1987, Moyle \& Cech 1988). The life histories of these species could be disrupted by changes in the timing, magnitude, and duration of the rainy or dry seasons. In coastal areas, sea level rise may alter the salinity of estuarine habitats, inundate wetlands, and reduce the abundance of or eliminate submerged vegetation, thereby adversely affecting those species which rely on these coastal habitats for reproduction and recruitment.

Three general approaches have been used to evaluate potential impacts to fisheries resources from climate change: (1) predicting changes in the availability of thermal habitat by evaluating changes in the thermal structure of lakes and streams (Christie \& Regier 1988, Magnuson et al. 1990, Matthews \& Zimmerman 1990); (2) predicting effects of temperature changes on physiological processes, particularly growth and feeding (Hill \& Magnuson 1990, McCauley \& Kilgour 1990 , Regier et al. 1990); and (3) predicting impacts of changes in physical habitat features (i.e. water temperatures, flow rates, and water levels) to important life history stages such as migration periods and spawning times (Table 1). These general approaches have been identified by some researchers as the basic framework for evaluating climate change impacts to fisheries resources (Regier \& Meisner 1990, Shuter \& Meisner 1992). Studies that have evaluated potential impacts of

Table 1. Assessment methods for evaluating the effects of climate change on fish resources

\begin{tabular}{|c|c|c|}
\hline Parameter & Method & Source \\
\hline Thermal habitat availability & $\begin{array}{l}\text { Predicted changes in the availability of suitable } \\
\text { thermal habitat from modeled water temperature } \\
\text { and thermal biology information }\end{array}$ & $\begin{array}{l}\text { Christie \& Regier (1988), Magnuson } \\
\text { et al. (1990), Matthews \& Zimmer- } \\
\text { man (1990), Coutant (1990), } \\
\text { Meisner (1990) }\end{array}$ \\
\hline Fish yields & Fish yield regression model & Schlesinger \& Regier $(1982,1983)$ \\
\hline \multirow{4}{*}{$\begin{array}{l}\text { Physiology, growth, } \\
\text { bioenergetics }\end{array}$} & Arrhenius models of process-response relationships & Regier et al. (1990) \\
\hline & Bioenergetics model & Kitchell et al. (1977) \\
\hline & Estimate availability of optimal growth temperatures & Hill \& Magnuson $(1990\}$ \\
\hline & Estimate available thermal growth units & McCauley \& Kilgour (1990) \\
\hline Life history effects & $\begin{array}{l}\text { Comparison of life history phenology with predicted } \\
\text { environmental changes }\end{array}$ & Coutant $(1990)$ \\
\hline
\end{tabular}


climate change on fisheries in temperate and northern latitudes have primarily followed the first 2 approaches, and have focused primarily on the thermal aspects of climate change. In addition, a number of studies have used empirically derived models to examine the relationships between fishery production (as yield or catch) and precipitation (Welcomme 1980 , Garcia \& Le Reste 1981. Tyus \& Karp 1991) or temperature (Schlesinger \& Regier 1982, 1983). Although many of these studies were not conducted specifically to evaluate potential climate change impacts, they represent a fourth approach for evaluating the effects of climate change on fish resources.

\section{LINKING CLIMATE CHANGE PREDICTIONS TO ECOLOGICAL RESPONSES}

Several general circulation models (GCMs) are available for predicting changes in climatic conditions for a $2 \times \mathrm{CO}_{2}$ scenario (Houghton et al. 1992). The model results provide predicted values for approximately 70 climatic variables, including air temperature, mean monthly precipitation, sea level rise, and solar radiation. For Africa, predicted changes in climate conditions vary among regions (Unganai 1996, this issue). Mean annual air temperatures may increase 3 to $4^{\circ} \mathrm{C}$, while precipitation may increase or decrease by as much as $20 \%$, depending on location. Although GCM outputs include predictions of air temperatures and precipitation magnitude, duration, and distribution, they do not provide direct information on water quality or hydrological parameters that affect fisheries resources. Thus, a fisheries vulnerability assessment must translate the predicted atmospheric climate changes into changes in lake and sea levels, stream flow, dissolved oxygen levels, and water temperatures (Meisner et al, 1987. Thomann \& Mueller 1987, Christie \& Regier 1988, Kennedy 1990, Rogers \& Fiering 1990, Schaake 1990). Only when these linkages are made can the ecological and biological responses (such as growth rates, reproductive success, mortality, and distribution) of fisheries resources to climate change be identified and evaluated (Fig. 1). Some approaches that have been used to link conditions in the aquatic environment to climatic conditions are identified in Table 2. These methods typically rely on large historic databases and use empirically derived models or complex computer models

\section{FISHERIES RESOURCES IN AFRICA}

The major aquatic habitats present in Africa include, but are not limited to, (1) the Great Rift Lakes such as
Lakes Malawi and Victoria, (2) man-made reservoirs such as Lake Kariba, (3) large river and floodplain systems such as the Nile and Zambezi Rivers, and (4) Coastal habitats including estuaries, mangrove swamps, and deltas. This diversity of habitats supports an even greater variety of ecologically and/or economically important species.

Ten ichthyofaunal regions based largely on presentday drainage systems have been delineated for Africa (Lowe-McConnell 1987). These are dominated by the Niger, Nile, Zaire, and Zambezi River systems, and also include several inland drainage areas associated with lakes. Among the riverine systems, the Zaire River (including its major tributaries) contains the most

\section{General Circulation Model predictions}

Altered air temperature, precipitation, solar radiation, wind speed

\section{$\downarrow$}

Link climate changes to marine and freshwater environmental conditions

- Predict surface water temperature from air temperature - Develop thermal profiles

- Predict sea and lake levels and river hydrographs

- Quantify physical changes in habitats due to changes

in sea and lake levels using topographic information

- Quantify areal extent of floodplain inundation

Identify habitat parameters vulnerable to predicted changes in marine and freshwater conditions and collect appropriate biological and fisheries data

- Physiological parameters (thermal niche and tolerance)

- Habitat requirements (flow, substrate, depth) and other life history information

- Individual process rates (growth and mortality rates)

- Historic fish yield or catch estimates

- Develop temperature-process relationships

\section{Implement assessment approaches}

- Develop empirical models to predict fish yields from historic data and GCM climate predictions

- Develop habitat suitability models and predict fisheries response to changes in habitat quality

- Evaluate changes in growth using bioenergetics model and temperature-process relationships

- Predict changes in habitat abundance and thermal suitability

Fig. 1. Conceptual framework for linking predicted climate changes to environmental conditions in aquatic habitats and predicting biological responses of target fish resources 
Table 2. Methods for linking predicted changes in climate to the physical conditions of surface waters

\begin{tabular}{|lll|}
\hline Parameter & Method & Source \\
\hline $\begin{array}{l}\text { Water temperature and } \\
\text { DO profiles: lakes }\end{array}$ & Hydrodynamic model & Bne-dimensional water quality model \\
Water temperature and & Stream temperature model & Stefan et al. (1993) \\
DO profiles: streams & Temperature model & Delay \& Seaders (1966) \\
Surface water temperature: & Regression analysis - water temperature vs air & Stefan \& Preud'homme (1993) \\
lakes & temperature and other variables & Schlesinger \& Regier (1983), Shuter \\
Lake levels & Stochastic water basin models & et al. (1983), Hill \& Magnuson (1990) \\
& One-dimensional water balance model & Rogers \& Fiering (1990) \\
Flows: rivers & Regression analysis using precipitation and stream & US Country Studies Program (1994) \\
& flow data & Byron et al. (1989) \\
& Regression analysis to develop stage-discharge & Gordon et al. (1992) \\
& relationships & \\
& Aerial photography to develop surface water area maps & Snider et al. (1994) \\
& Water balance models & Schaake (1990), US Country Studies \\
& & Program (1994)
\end{tabular}

diverse fish fauna (Table 3), with about 690 species of which $80 \%$ are endemic (Lowe-McConnell 1987). The lacustrine systems in Africa (particularly the rift valley lakes) contain the most diverse and unique fish assemblages found anywhere in Africa, if not the world. For example, Lake Malawi has more than 240 fish species of which more than $90 \%$ are endemic, and another $500+$ species are awaiting taxonomic identification (Lewis et al. 1986). In contrast, North America has 3 major ichthyofaunal regions with about 950 species, 740 species north of Mexico (Hocutt \& Wiley 1986. Moyle \& Cech 1988). The North American fish fauna is represented by 18 families, fewer than found in either the Niger or Zaire Rivers or in Lakes Chad or Tanganyika.

\section{FACTORS CONSIDERED DURING SELECTION AND EVALUATION OF ASSESSMENT METHODS}

In our selection and evaluation of methodologies that could be suitable for use in Africa, we focused on approaches that (1) are readily straightforward to implement, (2) do not require extensive computer equipment or specialized analytical instrumentation, (3) can be applied to a variety of species and habitats, and (4) can be completed in a timely manner (Sathaye \& Meyers 1995). The evaluation of assessment methods for applicability to Africa considered a number of environmental, biological, and technical issues, as well as time, effort, and cost constraints. Only limited resources are available for climate change country study vulnerability assessments. Countries have to fulfil their obligations to meet the needs of the UN Framework Convention on Climate Change (UNFCCC), and the availability of in-country technical staff needed to perform the assessments is variable and often limited (Dixon et al, 1996). These limitations largely rule out implementation of laboratory and field studies to generate new data. Instead, the assessments must rely largely on existing available data (Ramos-Mane \& Benioff 1995).

The African nations possess a variety of lacustrine, riverine, and marine habitats with over 800 species of

Table 3. Approximate numbers of fish families and species in the principle drainage basins of Africa (Lowe-McConnell 1987)

\begin{tabular}{|lccc|}
\hline Drainage basin & $\begin{array}{c}\text { No. of } \\
\text { families }\end{array}$ & $\begin{array}{c}\text { Total no. of } \\
\text { species }\end{array}$ & $\begin{array}{c}\text { No. of } \\
\text { cichlid species }\end{array}$ \\
\hline Niger River & 26 & 134 & 10 \\
Nile River & 17 & 115 & 10 \\
Zaire River & 24 & 690 & 40 \\
Zambezi River & 18 & 110 & 20 \\
Lake Chad & 23 & 176 & 13 \\
Lake Turkana & 15 & 39 & 7 \\
Lake Albert & 15 & 46 & 9 \\
Lake Edward/George & 8 & 57 & 40 \\
Lake Victoria & 12 & $238+$ & $200+$ \\
Lake Tanganyika & 19 & 247 & 136 \\
Lake Malawi & 9 & $242+$ & $200+$ \\
& & & \\
\hline
\end{tabular}


freshwater and marine species. Because of this great diversity in habitats and species, no single assessment approach is suitable for use by all countries or for all fisheries resources. A further complicating factor in selecting assessment methodologies for Africa is the limited availability of natural history, physiological ecology, limnology, hydrology, and fisheries yield data. Although technically complex methods using geographic information systems, remotely sensed data, and hydrodynamic models have been used in a number of climate change studies in other parts of the world (McCormick 1990, Minns \& Moore 1992), the necessary computer hardware and software for these approaches is frequently limited or unavailable in African nations. Although we targeted both freshwater and marine resources, the latter focused primarily on nearshore penaeid shrimp fisheries. Penaeid shrimp represent a major economic and subsistence fishery resource for coastal countries. Because the effects of climate on marine fisheries is best understood for coastal areas and poorly understood for deep water open ocean areas (Kennedy 1990), the marine methods we evaluated were limited to those applicable for nearshore environments only.

\section{APPROACH SUGGESTED FOR AFRICAN COUNTRIES}

As a result of the diversity of fisheries resources and aquatic habitats present in Africa and the inability of any single method or approach to adequately evaluate potential impacts to all the species and habitats present in any one country, we suggest a weight-of-evidence approach (EPA 1992) for evaluating potential climate change impacts on fisheries resources. A weight-of-evidence approach uses multiple lines of evidence to identify the nature and evaluate the significance of potential impacts. The assessment methods also represent a suite of approaches that can be tailored for a particular country, habitat type, climate variable, and fishery resource.

The methods identified for use in Africa target different aspects of the fisheries resources (Sagua 1993). Some methods evaluate the effects of climate change on habitat availability and suitability, while others evaluate the effects on growth, feeding, mortality, and timing of life history parameters. Still other methods evaluate the effects of climatic conditions on annual catch or yield. Many of the suggested methods require linking GCM predictions of air temperature and precipitation to changes in water temperature, hydrology, and sea level, while other methods use the GCM predictions directly (Regier \& Meisner 1990). The suggested methods do not address such ecologically important factors as nutrient cycling and primary productivity, eutrophication and other water quality issues, community structure and function, predatorprey interactions, or fishing methods, success, and pressure

Three categories of predictive models are represented by the methods identified in Tables 4-6: bioenergetics models, habitat suitability models, and empirical models. Bioenergetics modeling is directly applicable to evaluating the potential effects of climate change on fisheries resources and permits predictions of fish growth and biomass under different temperature scenarios (Hill \& Magnuson 1990). The use of habitat suitability models is identified for both freshwater and marine systems and permits evaluation of changes in the suitability of particular habitats relative to climate-driven changes in environmental conditions. Although there is some disagreement regarding the use of habitat suitability models, these models are used by the U.S. Fish and Wildlife Service and others to evaluate potential environmental impacts to fisheries resources (Armour \& Taylor 1991) and have been evaluated in South Africa and found to be useful for identifying minimum instream flows for endemic fish fauna of the Olifants River (Gore et al. 1991).

A number of the methods employ empirical models to predict a particular response by the fishery to a change in a particular climate-related variable or set of variables. For example, Pauly (1980) developed empirical models for predicting changes in the natural mortality in a fish stock as a result of changes in the average annual surface water temperature, while Sagua (1993) developed an empirical model to predict mean total catch from mean river discharge. Both mean annual surface water temperature and mean annual river discharge are direct functions of air temperature and precipitation, respectively. The use of site- and resource-specific empirical models, or models previously developed using African data, is strongly recommended because such models allow for a rapid evaluation of a fisheries response (such as mortality or yield) to a change in a climate-dependent environmental variable such as water temperature or stream flow.

Specific methods to address freshwater fisheries resources are summarized in Table 4, while methods for evaluating coastal marine penaeid shrimp resources are summarized in Table 5. Each of these methods evaluates the potential effects of a single climate-affected variable, namely water temperature, stream flow, and lake or sea level, and may or may not be species-specific. Three other methods, summarized in Table 6, employ species-specific bioenergetics, habitat suitability, and natural mortality approaches, can be used in either freshwater or 


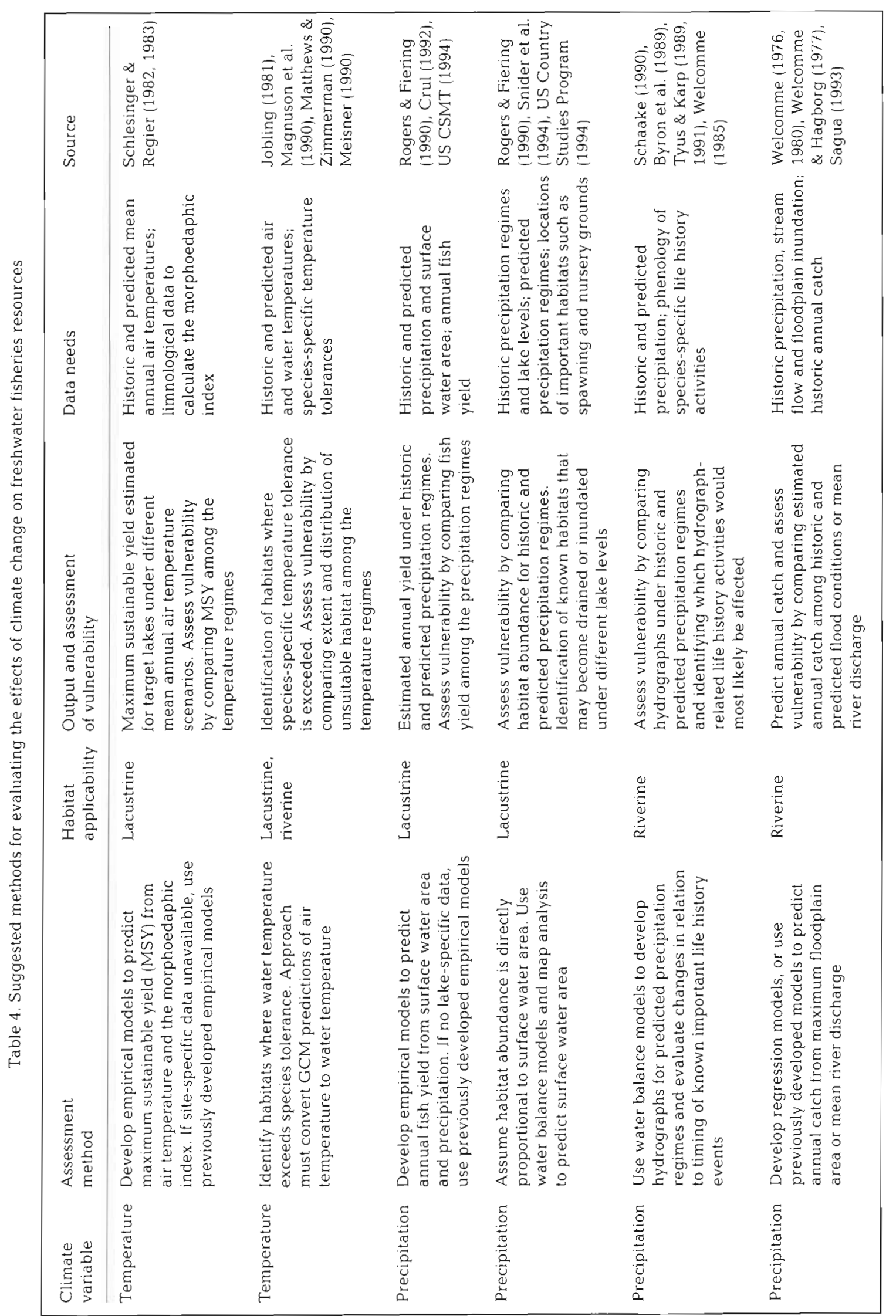


marine habitats, and can simultaneously evaluate multiple climate-affected variables. The choice of methods for use in any particular country will be dependent on the habitats and fisheries present in that country, the availability of environmental and ecological data, and the nature of the predicted change in climate.

\section{CONCLUSIONS}

\section{Selection of methods}

The methods identified in Tables $4-6$ represent 'suggested' assessment methods. Because it may be difficult to validate any particular method, it is recom-

Table 5. Suggested methods for evaluating the effects of climate change to coastal marine penaeid shrimp fisheries

\begin{tabular}{|c|c|c|c|c|}
\hline $\begin{array}{l}\text { Climate } \\
\text { variable }\end{array}$ & $\begin{array}{l}\text { Assessment } \\
\text { method }\end{array}$ & $\begin{array}{l}\text { Output and assessment } \\
\text { of vulnerability }\end{array}$ & Data needs & Source \\
\hline Precipitation & $\begin{array}{l}\text { Estimate total annual shrimp } \\
\text { catch using empirically } \\
\text { developed models that } \\
\text { predict catch to previous } \\
\text { years' total annual rainfall }\end{array}$ & $\begin{array}{l}\text { Models provide estimate of annual } \\
\text { shrimp catch. Vulnerability assessed } \\
\text { by comparing shrimp catch under } \\
\text { historic and predicted precipitation } \\
\text { regimes }\end{array}$ & $\begin{array}{l}\text { Historic and predicted } \\
\text { total annual rainfall; } \\
\text { historic annual shrimp } \\
\text { catch for each shrimp } \\
\text { fishery area of concern }\end{array}$ & $\begin{array}{l}\text { Garcia \& Le } \\
\text { Reste (1981) }\end{array}$ \\
\hline Temperature & $\begin{array}{l}\text { Estimate shrimp yield from } \\
\text { mean annual air temperature } \\
\text { using exponential relationships } \\
\text { of the Arrhenius form developed } \\
\text { with site-specific data. If site- } \\
\text { specific data are unavailable use } \\
\text { previously developed models }\end{array}$ & $\begin{array}{l}\text { Models predict annual shrimp yield. } \\
\text { Assess vulnerability by comparing } \\
\text { annual yield under historic and } \\
\text { predicted air temperatures }\end{array}$ & $\begin{array}{l}\text { Historic and predicted } \\
\text { mean annual air } \\
\text { temperatures and com- } \\
\text { mercial shrimp yield } \\
\text { for the shrimp fishery } \\
\text { area of concern }\end{array}$ & $\begin{array}{l}\text { Regier et al. } \\
(1990)\end{array}$ \\
\hline Sea level & $\begin{array}{l}\text { Developed empirical models } \\
\text { to predict annual shrimp } \\
\text { yield from areal size of } \\
\text { known shrimp habitats. Use } \\
\text { map analysis to estimate } \\
\text { changes in habitat size due } \\
\text { to sea level rise }\end{array}$ & $\begin{array}{l}\text { Model is used to estimate annual } \\
\text { shrimp yield for different habitat sizes. } \\
\text { Changes in shrimp habitat due to sea } \\
\text { level rise are then used to predict } \\
\text { shrimp yield. Vulnerability is assessed } \\
\text { by comparing. In the absence of } \\
\text { historic yield data, annual yield may } \\
\text { be inferred from differences in } \\
\text { habitat availability }\end{array}$ & $\begin{array}{l}\text { Areal abundance of } \\
\text { aquatic vegetation and } \\
\text { historic annual shrimp } \\
\text { yield for the shrimp } \\
\text { fishery area of concern }\end{array}$ & $\begin{array}{l}\text { Turner } \\
(1977,1992) \\
\text { Turner \& } \\
\text { Boesch } \\
(1988)\end{array}$ \\
\hline
\end{tabular}

Table 6 . Suggested methods for evaluating the effects of climate change on fisheries resources in freshwater and marine habitats

\begin{tabular}{|c|c|c|c|c|c|}
\hline $\begin{array}{l}\text { Climate } \\
\text { variable }\end{array}$ & $\begin{array}{l}\text { Assessment } \\
\text { method }\end{array}$ & $\begin{array}{l}\text { Habitat } \\
\text { applicability }\end{array}$ & $\begin{array}{l}\text { Output and assessment } \\
\text { of vulnerability }\end{array}$ & Datâ needs & Source \\
\hline Temperature & $\begin{array}{l}\text { Estimate species- } \\
\text { specific growth and } \\
\text { feeding rates under } \\
\text { different temperature } \\
\text { regimes using Fish } \\
\text { Bioenergetics Model } 2\end{array}$ & $\begin{array}{l}\text { Lacustrine, } \\
\text { riverine, } \\
\text { and coastal } \\
\text { marine }\end{array}$ & $\begin{array}{l}\text { Assess vulnerability by com- } \\
\text { paring growth and feeding rates } \\
\text { among historic and predicted } \\
\text { temperature scenarios }\end{array}$ & $\begin{array}{l}\text { Species-specific } \\
\text { bioenergetics data } \\
\text { (i.e. respiration and } \\
\text { ingestion rates; } \\
\text { historic and predicted } \\
\text { temperature regimes) }\end{array}$ & $\begin{array}{l}\text { Kitchell et al. } \\
\text { (1977), Hill \& } \\
\text { Magnuson } \\
\text { (1990), Hew- } \\
\text { ett \& Johnson } \\
\text { (1992) }\end{array}$ \\
\hline Temperature & $\begin{array}{l}\text { Use empirical model } \\
\text { to estimate species- } \\
\text { specific natural } \\
\text { mortality rates }\end{array}$ & $\begin{array}{l}\text { Lacustrine, } \\
\text { riverine, } \\
\text { and coastal } \\
\text { marine }\end{array}$ & $\begin{array}{l}\text { Estimate natural mortality rates } \\
\text { and assess vulnerability by } \\
\text { comparing rates among historic } \\
\text { and predicted air temperatures }\end{array}$ & $\begin{array}{l}\text { Historic and predicted } \\
\text { air temperatures; } \\
\text { species-specific asymp- } \\
\text { totic length or weight }\end{array}$ & $\begin{array}{l}\text { Pauly (1980, } \\
\text { 1983) }\end{array}$ \\
\hline $\begin{array}{l}\text { Precipitation } \\
\text { and } \\
\text { temperature }\end{array}$ & $\begin{array}{l}\text { Develop species- } \\
\text { specific habitat suit- } \\
\text { ability index (HSI) } \\
\text { models that incorp- } \\
\text { orate water tempera- } \\
\text { ture and hydrology } \\
\text { as habitat variables }\end{array}$ & $\begin{array}{l}\text { Lacustrine, } \\
\text { riverine, } \\
\text { and coastal } \\
\text { marine }\end{array}$ & $\begin{array}{l}\text { Estimate habitat suitability } \\
\text { for specific habitats using HSI } \\
\text { models and assess vulnerability } \\
\text { by comparing values under } \\
\text { historic and predicted climate } \\
\text { scenarios }\end{array}$ & $\begin{array}{l}\text { Historic and predicted } \\
\text { hydrological conditions } \\
\text { and water temperatures; } \\
\text { species-specific habitat }\end{array}$ & $\begin{array}{l}\text { Turner \& } \\
\text { Brody (1983), } \\
\text { Hays (1987), } \\
\text { Crance }(1987)\end{array}$ \\
\hline
\end{tabular}


mended that as many of the suggested methods as possible be implemented to adequately evaluate impacts to fisheries (Sagua 1993). However, final selection of methods will be largely dependent on the nature of the fisheries resource of concern and on the availability of appropriate data. Short of extensive, long-term, experimental field and laboratory investigations, the methods identified provide the best predictions possible, within their limitations (Sathaye \& Meyers 1995).

The final choice of methods is at the discretion of the fisheries staff that will be performing the actual assessment. For each fishery type (lacustrine, riverine, and coastal marine), the in-country staff may select 1 or more of each of the suggested approaches, or may opt to use other methods not identified in this report.

\section{Integration of results and determinations of vulnerability}

The approaches identified for use in evaluating potential climate change impacts to freshwater lacustrine and riverine and coastal marine fisheries resources in Africa represent a dichotomy of methods. Methods such as the bioenergetics and habitat suitability models will permit the evaluation of potential climate change impacts to individual species. In contrast, other methods evaluate potential impacts to overall yield or catch. These latter methods cannot be used to identify potential effects of climate change on individual species of concern.

The species-specific approaches will be the most problematic to employ, largely due to the relative absence of species data on life history and physiology. In the absence of species-specific data, professional judgement may be used to estimate life history and bioenergetics variables. Difficulties associated with developing empirical models for predicting catch from environmental conditions will be largely associated with the absence of hydrological and environmental data.

As previously discussed, the overall approach for identifying potential impacts from climate change to fisheries resources follows a 'weight-of-evidence' approach. This approach relies on multiple lines of evidence to evaluate the potential for adverse or beneficial impacts to fisheries from climate change. However, the methods identified in this report are not fully integrated and could give conflicting results or, mare likely, results in the same direction but of differing magnitudes. For example, estimates of mortality using the relationships developed by Pauly (1980) may indicate adverse impacts under a particular climate-temperature scenario, while estimates of maximum sustainable yield using the relationships of Schlesinger \&
Regier (1982) may indicate a positive impact under the same temperature scenario. The evaluation of multiple results may rely heavily on the professional judgement of the fishery biologists performing the vulnerability assessment. It should be remembered that the results of the fisheries vulnerability assessment are not intended to provide a quantitative, definitive identification of the nature and magnitude of impacts to fisheries resources that would occur for a particular change in climate. Rather, the assessment is meant to provide an indication of the potential of adverse impacts to fisheries resources, and provide a preliminary indication if, or which, fisheries resources may be at risk.

Acknowledgements. We thank $\mathrm{W}$. Hubert, $\mathrm{H}$. Regier, $\mathrm{V}$. Kennedy, J. Eaton and R. Welcomme for providing comments on earlier versions of this manuscript.

\section{LITERATURE CITED}

Armour CL, Taylor JG (1991) Evaluation of the instream flow incremental methodology by U.S. Fish and Wildlife Service field users. Fisheries 16:36-43

Blumberg AF, Di Toro DM (1990) Effects of climate warming on dissolved oxygen concentrations in Lake Erie. Trans Am Fish Soc 119:224-239

Byron ER, Jassby A, Goldman CR (1989) The effects of global climate change on the water quality of mountain lakes and streams, Chap 4. In: Smith JB, Tirpak DA (eds) The potential effects of global climate change on the United States, Appendix E, Aquatic resources. EPA-230-05-89055. US Environmental Protection Agency, Washington, DC

Carpenter SR, Fisher SG, Grimm NB, Kitchell JF (1992) Global change and freshwater ecosystems. A Rev Ecol Syst 1992 23:119-139

Christie GC, Regier HA (1988) Measures of optimal thermal habitat and their relationship to yields of four commercial fish species. Can J Fish Aquat Sci 45:301-314

Coutant CC (1990) Temperature-oxygen habitats for freshwater and coastal striped bass in a changing climate. Trans Am Fish Soc 119:240-253

Crance JH (1987) Guidelines for using the Delphi technique to develop habitat suitability index curves. Biological Report 82 (10.134), U.S. Fish and Wildlife Service, Washington, DC

Crul RCM (1992) Models for estimating potential tish yields of African inland waters. CIFA Occasional Paper No. 16, Food and Agriculture Organization of the United Nations, Rome

Delay WH, Seaders J (1966) Predicting temperatures in rivers and reservoirs. J Sanit Eng Div, Am Soc Civil Eng 92: $115-134$

Dixon RK, Sathaye JG, Meyers SP, Masera OR, Makarov AA, Toure S, Makundi W, Wiel S (1996) Greenhouse gas mitigation strategies: preliminary results from the U.S. Country Studies Program. Ambio (in press)

EPA (1992) Framework for ecological risk assessment. EPA/630/R-92/001, Risk Assessment Forum, US Environmental Protection Agency, Washington, DC

Garcia S, Le Reste L (1981) Life cycles, dynamics, exploita- 
tion, and management of coastal penaeid shrimp stocks. FAO Technical Paper No. 203, Food and Agriculture Organization of the United Nations, Rome

Gordon ND, McMahon PA, Finlayson BL (1992) Stream hydrology. John Wiley \& Sons, New York

Gore JA, King JM. Hamman KCD (1991) Application of instream flow incremental methodology to Southern African rivers: protecting endemic fish of the Olifants River. Water S A 17:225-236

Hays RL (1987) A users manual for Micro-HSl, habital suitability index modeling software for microcomputers, Version 2. National Ecology Center, U.S. Fish and Wildlife Service, Fort Collins, CO

Hewett SW. Johnson BL (1992) Fish bioenergetics model 2. WIS-SG-91-250, University of Wisconsin Sea Grant Institute, Madison

Hill DK, Magnuson JJ (1990) Potential effects of global climate warming on the growth and prey consumption of Great Lakes fish. Trans Am Fish Soc 119:265-275

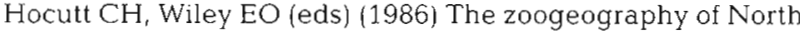
American freshwater fishes. John Wiley and Sons, New York

Houghton JT, Callendar BT, Varney SK (eds) (1992) The supplemental report to the IPCC scientific assessment. IPCC Cambridge University Press, Cambridge

Jobling $M$ (1981) Temperature tolerance and the final preferendum - rapid methods for the assessment of optimum growth temperatures. J Fish Biol 19:439-455

Kennedy VS (1990) Anticipated effects of climate change on estuarine and coastal fisheries. Fisheries 15(6):16-24

Kitchell JF, Stewart DJ, Weininger D (1977) Applications of a bioenergetics model to yellow perch (Perca flavescens) and walleye (Stizostedion vitreum vitreum). J Fish Res Bd Can 34:1922-1935

Lewis D, Reinthal P, Trendall J (1986) A guide to the fishes of Lake Malawi National Park. World Wildlife Fund, World Conservation Centre, Gland

Lowe-McConnell RH (1987) Ecological studies in tropical fish communities. Cambridge University Press, Cambridge

Magnuson JJ, Meisner JD, Hill DK (1990) Potential changes in the thermal habitat of Great Lakes fish after global climate warming. Trans Am Fish Soc 119:254-264

Matthews WJ, Zimmerman EG (1990) Potential effects of global warming on native fishes of the southern great plains and the southwest. Fisheries 15:26-32

McCauley RW, Kilgour DM (1990) Effect of air temperature on growth of largemouth bass in North America. Trans Am Fish Soc 119:276-281

McCormick MJ (1990) Potential changes in thermal structure and cycle of Lake Michigan due to global warming. Trans Am Fish Soc 119:183-194

Mearns LO, Gleick PH, Schneider SH (1990) Climate forecasting. In: Waggoner PE (ed) Climate change and U.S water resources. John Wiley and Sons, New York, p $87-137$

Meisner JD (1990) Potential loss of thermal habitat for brook trout, due to climatic warming, in two southern Ontario streams. Trans Am Fish Soc 119:282-291

Meisner JD, Goodier JL, Regier HA, Shuter BJ, Christie WJ (1987) An assessment of the effects of climate warming on Great Lakes basin fishes. J Great Lakes Res 13: $340-352$

Meisner JD, Shuter BJ (1992) Assessing potential effects of global climate change on tropical freshwater fishes. GeoJournal 28:21-27

Minns CK, Moore JE (1992) Predicting the impact of climate change on the spatial pattern of freshwater fish yield capability in eastern Canada. Clim Change 22:327-346

Moyle PB, Cech JJ Jr (1988) Fishes: an introduction to ichthyology. Prentice Hall, Englewood Cliffs, NJ

Pauly D (1980) On the interrelationships between natural mortality, growth parameters, and mean exvironmental temperature in 175 fish stocks. J Cons Int Explor Mer 39(2): $175-192$

Pauly D (1983) Some simple methods for the assessment of tropical fish stocks. FAO Fisheries Technical Paper No. 234, Food and Agriculture Organization of the United Nations, Rome

Ramos-Mane C, Benioff R (1995) Interim report on climate change country studies. DOE/PO-0032, U.S. Department of Energy, Washington, DC

Regier HA, Holmes JA, Pauly D (1990) Influence of temperature changes on aquatic ecosystems: an interpretation of empirical data. Trans Am Fish Soc 119:374-389

Regier HA, Meisner JD (1990) Anticipated effects of climate change on freshwater fishes and their habitat. Fisheries 15:10-15

Rogers PP, Fiering MB (1990) From flow to storage. In: Waggoner PE (ed) Climate change and U.S. water resources. John Wiley and Sons, New York, p 207-221

Sagua VO (1993) The effects of climate change on the fisheries of the Sahel. Food and Agriculture Organization of the United Nations, Rome

Sathaye J, Meyers S (eds) (1995) Greenhouse gas mitigation assessment: a guidebook. Kluwer Academic Publishers, Dordrecht

Schaake JC (1990) From climate to flow. In: Waggoner PE (ed) Climate change and U.S. water resources. John Wiley and Sons, New York, p 177-206

Schlesinger DA, Regier HA (1982) Climatic and morphoedaphic indices of fish yields from natural lakes. Trans Am Fish Soc 111:141-150

Schlesinger DA, Regier HA (1983) Relationship between environmental temperature and yields of subarctic and temperate zone fish species. Can J Fish Aquat Sci 40: $1829-1837$

Shuter BJ, Meisner JD (1992) Tools for assessing the impact of climate change on freshwater fish populations. GeoJournal 28:7-20

Shuter BJ, Schlesinger DA, Zimmerman AP (1983) Empirical predictors of annual surface water temperature cycles in North American lakes. Can J Fish Aquat Sci 40:1838-1845

Smith JB, Tirpak D (eds) (1989) The potential effects of global climate change on the United States. Policy, planning, and evaluation. U.S. Environmental Protection Agency, Washington, $\mathrm{DC}$

Snider MA, Hayse AW, Hlohowskyj I, LaGory K (1994) Multispectral airborne videography evaluates environmental impact. GIS World $7(6): 50-52$

Stefan HG, Hondzo M, Fang X (1993) Lake Water quality modeling for projected future climate scenarios. J Environ Qual 22:417 -431

Stefan HG, Preud'homme EB (1993) Stream temperature estimation from air temperature. Water Res Bull 29:27-45

Thomann R, Mueller J (1987) Principles of surface water quality modeling and control. Harper and Row, Inc, New York

Turner RE (1977) Intertidal vegetation and commercial yields of penaeid shrimp. Trans Am Fish Soc 106(5):411-416

Turner RE (1992) Coastal wetlands and penaeid shrimp habitat. In: Stroud RH (ed) Stemming the tide of coastal fish habitat loss. Marine Recreational Fisheries Report No. 14, National Coalition for Marine Conservation, Inc, Savannah, GA, p 97-104 
Turner RE, Boesch DF (1988) Aquatic animal production and wetland relationships: insights gleaned following wetland loss or gain. In: Hook DD et al. (eds) The ecology and management of wetlands, Vol 1, Ecology of wetlands. Timber Press, Portland, OR, p 25-39

Turner RE, Brody MS (1983) Habitat suitability index models. northern Gulf of Mexico brown shrimp and white shrimp. FWS/OBS-82/10.54, U.S. Dept of the Interior, Fish and Wildlife Service, Washington, DC

Tyus HM, Karp CA (1989) Habitat use and streamflow needs of rare and endangered fishes, Yampa River, Colorado. U.S. Fish and Wildlife Service Biological Report 89(14), U.S. Dept of the Interior, Fish and Wildlife Service, Washington, DC

Tyus HM, Karp CA (1991) Habitat use and streamflow needs of rare and endangered fishes in the Green River Utah. U.S. Fish and Wildlife Service, Flaming Gorge Studies Program, Colorado River Fishes Project, Vernal, UT
Unganai LS (1996) Historic and future climatic change in Zimbabwe. Clim Res 6:137-145

U.S. Country Studies Program (1994) Guidance for vulnerability and adaptation assessments, Version 1.0. U.S. Country Studies Management Team, Washington, DC

Welcomme RL (1976) Some general and theoretical considerations on the fish yield of African rivers. J Fish Biol 8: $351-364$

Welcomme RL (1980) Some factors affecting the catch of tropical river fisheries. In: Comparative studies on freshwater fisheries. FAO Fisheries Technical Paper No. 198, Food and Agriculture Organization of the United Nations, Rome, p 268-275

Welcomme RL (1.985) River fisheries. FAO Fisheries Technical Paper No. 262, Food and Agriculture Organization of the United Nations, Rome

Welcomme RL, Hagborg D (1977) Towards a model of a floodplain fish population and its fishery. Environ Biol Fish 2(1): $7-24$ 